\title{
Policy Formulation of Criminal Law against Narcotics Traffickers Based On Justice Value
}

\author{
Ade Christian Manapa ${ }^{1}$
}

Abstract. Act No. 35 of 2009 on Narcotics there are multiple interpretations and ambiguities article formulation, namely Article 112 of Law on Narcotics. Article resulted in the perpetrators of Narcotics (trafficker) will shelter as if he was a victim of crime or narcotics abusers.

The problems are: 1) Are Policy Formulation of Criminal Law Against Narcotics Traffickers based on Act No. 35 of 2009 has fulfilled a Justice Value? 2) How does the Policy Formulation of Criminal Law Against Narcotics Traffickers in Criminal Justice in Indonesia? and 3) how the Policy Formulation of Upcoming Criminal Law Against The Perpetrators And Abusers Based on Justice Value?

The method used is normative, the specification of the research is descriptive analytical data using secondary data sources, data collection methods using literature study, data presentation in the narrative, qualitative data analysis. The research problem in accordance with the above described problems he infused with three theories: 1 ) The theory of law enforcement, 2) Theory of legal certainty and 3) Theory of justice.

Result: 1) Policy Formulation of Criminal Law Against Narcotics Traffickers Based On Act No. 35 of 2009 still indicates ambiguity and multiple interpretations. Between the formulation of article 112 and article 127 so that it can ensnare abusers of narcotics in Article 127.2) Policies application of criminal law against traffickers Narcotics in Criminal Justice in Indonesia is still problematic, where the dealer the crime of Narcotics can shelter as abusers of narcotics to avoid criminal sanctions are more severe. 3) Policy criminal law traffickers and abusers of narcotics in the future is the need to change the formulation of Article 112 Law on Narcotics, ie there must be firmness that met the elements "have", "save", "master" or "buy" is a chapter devoted to trafficker, importers, producer, and another narcotics crime qualification and not pointed to narcotic abuse itself.

Keywords: Policy Formulation of Criminal Law; Narcotics Traffickers; Justice Value.

\section{Introduction}

In cases of narcotics, there are several articles that are often used to ensnare trafficker, namely Article 112, Article 114, and Article 127 Law on Narcotics. The third chapter, there are two chapters that multiple interpretations and ambiguities in the formulation, Article 112 and Article 127 Law on Narcotics. Article 112 paragraph (1) of Act No. 35 of 2009 states that any person who unlawfully or unlawfully possess, store, control, or provides Narcotics Group I not plant, shall be punished with imprisonment for a minimum of 4 (four) years and maximum 12 years and fined at least $R p 800,000$ $.000,00$ and most $\mathrm{Rp} 8,000,000,000.00$.

Furthermore, in Article 127, paragraph 2 of Act No. 35 of 2009 states, in deciding the case referred to in paragraph (1), the judge shall take into account the provisions referred to in article 54, article 55, and article 103 of Law on Narcotics. The third

\footnotetext{
1 Student of Master of Law, Sultan Agung Islamic University (UNISSULA), Semarang Email: chrismanapa73@gmail.com
} 
chapter it requires and provides guidelines for the judge to put the narcotics into medical and social rehabilitation institutions.

For example, in July 2017, among reported a convicted narcotic Sutrisno Nugroho filed a judicial review of Act No. 35 of 2009 on narcotics-related criminal sanctions for perpetrators of abuse of narcotics. Applicant was harmed by the application of Article 112, Article 114, and Article 127 Narcotics Law, which contains criminal sanctions for perpetrators of abuse of narcotics. Sutrisno subject to Article 112 and Article 114 regulations, known as the Narcotics Act, but these two articles should be charged to the dealer. But Article 127 is precisely removed and is not applied to the wearer or drug users, so that the applicant also lost the right to be given the chance of rehabilitation. ${ }^{2}$

This is different from the case of Decision No. 161 / Pid.Sus / 2016 / PN.Plg. In such cases the defendant was indicted as perpetrators or narcotics traffickers, but the judges in their verdict that the defendant is a drug user. The case with the defendant named Dedy Sanjaya and M Kiki Prataman. Both of the accused by the public prosecutor charged with the first Article 114 Paragraph (1) in conjunction with Article 132 Paragraph (1) of the Narcotic Drugs and / or the second charge, namely Article 112 Paragraph (1) of the Law on Narcotics, and / or indictment third, Article 127 Paragraph (1) Letter a Narcotics Act in conjunction with Article 55 Paragraph (1) 1st Criminal Code. In this case the defendant proved to master and has a first class Narcotic not plant as much as 1 pack of Shabu weighing 0.73 grams. From the discovery of the evidence should the accused charged based on Article 112 of Act No. 35 of 2009 on Narcotics. ${ }^{3}$

Lack of clarity of the formulation and multiple interpretations of Article 112 and Article 127 of Act No. 35 Of 2009 on Narcotics, gave rise to interest the authors to study it by doing research with the title "Policy Formulation of Criminal Law Against Narcotics Traffickers Based On Justice Value".

Based on the description of the background, then the problem can be formulated as follows: Does the Policy Formulation of Criminal Law Against Narcotics Traffickers Based On Act No. 35 of 2009 Justice Value?; How the Policy Formulation of Criminal Law Against Narcotics Traffickers in Criminal Justice in Indonesia?; How to Policy Formulation Upcoming On Criminal Law Against The Narcotics Perpetrators and Abusers Based On Justice Value?

\section{Research Methods}

The method used in this research is normative juridical approach, a study that emphasizes the science of law, but in addition, it is also trying to examine the legal principles that apply in the community. Judicial approach in this study is intended that this study the terms of the science of law and other written regulations relating to policy formulation of criminal law against the perpetrators and abusers of narcotics.

Specification used in this research is descriptive analytical, that picture is clear, detailed and systematic. It said because the analytical data obtained will be analyzed

\footnotetext{
${ }^{2}$ Huesin Abdulsalam, "Dilema Hukuman Rehabilitasi Narkoba", (https://tirto.id Accessed June 20, 2019)

${ }^{3}$ Fitri Resnawardhani, "Kepastian Hukum dalam Pasal 112 dan Pasal 127 Undang-Undang Nomor 35 Tahun 2009 Tentang Narkotika” Lentera Hukum, Volume 6 Issues 1, 2019, p. 119.
} 
for a solution to the problem in accordance with the provisions of applicable law. This study provides an overview of the policy formulation of criminal law against the perpetrators and abusers of narcotics.

\section{Results And Discussion}

\subsection{Policy Formulation Of Criminal Law Against Perpetrators and Narcotics Abuse Based On Act No. 35 of 2009 Already Has On Justice Value}

Based on the formulation of Article 112 of Act No. 35 of 2009 is known that in the legislation still using political means of penal (penal policy) in tackling the dangers of drug abuse. The penal policy stated in terms of punishment which regulates the action without rights and against the law. According to Barda Nawawi Arief the penal or criminal proposition is still important to use in tackling crime, namely:

- Criminal sanctions are necessary, we can not live, now and in the future will come without punishment;

- Criminal sanctions are the means best available, we have to deal with crimes or major hazards as well as to confront the threats of harm;

- Criminal sanctions once the main guarantor / best and once the main threatening of human freedom. He is the guarantor if used sparingly, carefully and humanely, he was threatening when used carelessly and forcibly.

The formulation of Article 112 of Act No. 35 Of 2009 on Narcotics is not concerned with intentional element of the crime of narcotics. The use of the word "Any person without rights or against the law" here gives the impression not considering the element of intent, can ensnare people who did not actually have the intention of committing a crime narcotics, either because of their compulsion, insistence, or unknown. This article also uses minimal criminal system. The use of minimal criminal system reinforces the assumption that this article is enacted to criminalize the people associated with narcotics. The use of minimal criminal will also be shut judges in decisions although in practice, the judge can pronounce sentence less than the minimum punishment and it is allowed by the Chief Justice.

So according to the author policy formulation is a policy that is strategic and decisive, because of errors in legislation policy will affect the applicable policies / judiciary. Examined from the optical material criminal law the Act No. 35 of 2009 on Narcotics have some type of formulation system of criminal sanctions. Cumulative formulation systems - substantially alternative formulation system also includes a single, cumulative and alternative, so explicitly and implicitly cover the weaknesses of each system of the formulation. Cumulative formulation system the alternative is a pattern that directly formulation system is characterized by a combination of legal certainty shades (rechts-zekerheids) and feel justice.

\subsection{Policy Formulation Of Criminal Law Against Narcotics Traffickers Based On Justice Value In Indonesia}

According to the author's opinion, if Article 127 of Act No. 35 of 2009 shall be imposed on the defendant, then there is a chance to be rehabilitated if based on examination of the accused is no potential for addiction. But if he had not proved 
his addiction, Article 112 paragraph (1) can wear to the accused based on the evidence that was found. In the end it all back on the wisdom and confidence of judges in examining whether the defendant feasible and proven terminated Article 112 paragraph (1) or Article 127 of Act No. 35 Of 2009 on Narcotics.

In practice, judges in assessing an event is also based on jurisprudence on previous decisions of the same case. If he is not proven as a seller and a positive urine result there is a tendency of judges to decide Article 127. In this case the judge referring to the Supreme Court Circular (SEMA) No. 4 of 2010 on the Establishment of abusers and addicts in Narcotics Rehabilitation Institute of Medical and Social Rehabilitation, The provisions of the SEMA is that the application of punishment as referred to in Article 103 letters a and b of Law of the Republic of Indonesia Number 35 Of 2009 on Narcotic only be imposed by criminal classification as follows:

- Defendant at the time was arrested by police investigators and investigators BNN in a state caught in the act;

- At the time caught in the act according to item $A$ above found used evidence in 1 (one) day.

In terms of sentencing judges handed down a command to do any legal action themselves in rehabilitation of the defendant, the judge must appoint expressly rehabilitation places nearest to his decision. To bring down the lengthy process of rehabilitation, the judge must seriously consider the condition or level of addiction of the accused, making it mandatory needed information from an expert and as a standard in the process of therapy and rehabilitation. SEMA is then updated with SEMA No. 3 of 2011 on Narcotics Abuse Victims Placement in Rehabilitation Institute of Medical and Social Rehabilitation.

Birth of SEMA is intended to clarify the interpretation of who the abusers of narcotics and contrario show if a person has, storing, controlling or providing narcotics more than the amount specified in the SEMA can not necessarily be said to be a drug abuser. That is if they have the criteria of Narcotics above could be qualified as criminal offenses Narcotics trafficker which closed an opportunity to be rehabilitated. ${ }^{4}$ SEMA is also intended that the judges have obvious limitations in terms of what a person although it has had, storing, controlling or providing narcotics said to be abusers of narcotics and vice versa in the case of what is seen as the perpetrator of the crime of Narcotics (trafficker) are consequential subject to Article 112 of Law on Narcotics.

The author hopes that the application of Rule of Law Judges in checking the defendant is based on existing evidence. It allows an easier Narcotics traffickers to fool officers, by bringing Narcotics little by little (less than 1 gram) and also using drugs. Thus, if caught on the existing evidence and urine tests will show that he was a narcotics abusers and not a dealer. Verdict based on the number of items of evidence as stipulated in the SEMA No. 4 of 2010 allows the Narcotics traffickers escape from the law and will only get light sentences.

\footnotetext{
${ }^{4}$ Tri Agus Gunawan, “Analisis Yuridis Terhadap Ketentuan Pasal 112 Ayat (1) Undang-Undang Nomor 35 Tahun 2009 Tentang Narkotika Pada Pecandu dan Penyalahguna Narkotika, Tesis, Universitas Islam Indonesia, 2013, p.166
} 


\subsection{Policy Formulation of Criminal Law In The Coming Of The perpetrators and abusers Based on Justice Value}

The judge in the verdict independence. Judges should not be influenced by anyone during their duties, the objective truth that the judge obtaining a court can deliver justice in its decision. But on the other hand, judges also have an attachment. The judge attached to the indictment the prosecutor, because the decision must be referred to the indictment. The indictment is the scope of the case, as a problem that must be addressed in the judge's decision. The judge also bound by means of legal evidence in court, as a material for assessing the indictment. Then the judge is bound in its own deliberations in the decision, as the reasons for sentencing a case. With the minimum and maximum criminal penalty,

But that mattered, a high minimum criminal sanctions are not necessarily known and considered by the majority of citizens. So how about the case of an offender who are new to narcotics, which have only one or two eggs, and even then because it was given by a friend, or offered from an unknown person is said to be tried. Then the perpetrator came from economically weak groups. Apparently the results of laboratory of its kind Narcotics is class I. It would have been unfair if he gets severe punishment of at least 4 years, while relatively simple criminal acts and the perpetrators belong to the weak economy.

Although these laws determine the minimum limit of punishment, MA openly by Circular No. 32015 on the Application of Formulation Room Plenary Meeting Results MA in 2015 as Guidelines Task For the Court, these provisions deviate. In the SEMA, the Court declared that "the Judge to examine and decide the case should be based on the indictment Public Prosecutor (Article 182 paragraph 3 and 4 of the Criminal Procedure Code). Prosecutors charged with Article 111 or Article 112 of Act No. 35 Of 2009 on Narcotics but based on legal facts revealed at the trial proved to Article 127 of Act No. 35 Of 2009 on Narcotics which this article is not indicted, the defendant is proven as a user and the amount relatively small (SEMA No. 4 of 2010), With abolish criminal provisions and required to rehabilitate abusers of narcotics for myself at least it can save the present and future of the abusers, and on the other hand can reduce the burden of conflict and loss experienced by the country. During this time the users Narcotics are caught and prosecuted, much more that goes into the prison than a rehabilitation center. It causes almost all prisons, more than half the residents were convicted of narcotics. Therefore, the revision of the Narcotics Act, the concept of a minimum quantity to be used as a reference in the categorization of narcotics abuse and crime. ${ }^{5}$

Sanctions action in the form of rehabilitation for abusers of narcotics for himself in accordance with the purpose of punishment is legal certainty theory and the theory of justice that found very inappropriate criminalization directed at criminals, not on deeds. Punishment is meant by this stream is to provide care measures through rehabilitation and repairs (rehabilitation) to offenders in lieu of punishment. This flow is based on the grounds that the offender is a sick person, which would require maintenance and repairs (rehabilitation). ${ }^{6}$

\footnotetext{
${ }^{5}$ Merevisi Undang-Undang Narkotika, (https://hukum.tempo.co, Accessed 20 September 2019).

${ }^{6}$ Hartanto Pakpahan, op.cit., p.240.
} 


\section{Closing}

\subsection{Conclusion}

- Policy formulation of criminal law against the perpetrators and Narcotics trafficker based on Act No. 35 of 2009 still indicates ambiguity and multiple interpretations. The formulation of Article 112 can ensnare abusers of narcotics as provided for in Article 127. Instead Narcotics traffickers in Article 112 could take refuge with Article 127 Narcotics Act if evidence is found small amounts as set forth in (SEMA) No. 4 of 2010 and a urine test result is positive, and this no Justice Value in the application of the Criminal Law.

- Policy Formulation of Criminal Law Against Narcotics Traffickers in Criminal Justice in Indonesia still raises many legal issues. Narcotics traffickers can take shelter as abusers of narcotics to avoid more severe criminal sanctions with the SEMA No. 4 of 2010 if evidence is found few.

- Policy Formulation of Criminal Law dealer Narcotics in the future is the need to change the formulation of Article 112 Law on Narcotics, ie there must be firmness that meet the elements "have", "save", "master" or "buy" is a chapter devoted to the trafficker, importers, people who manufacture and qualification of the crime of Narcotics others and not aimed at abusers of narcotics for themselves. If the abuser Narcotics evident that the attitude of the mind (Mens Rea / criminal intention) of the offender is no more than to be used for themselves judge is required to decide to apply sanctions, the form of medical rehabilitation and social rehabilitation for the offender.

\subsection{Suggestion}

- For law enforcement officers are expected to no longer criminalize addicts or abusers of narcotics in order to achieve the purpose of the law in the formation of the Narcotics Act.

- Need for change in the Narcotics Law, especially the provisions of Article 112 so that in practice there is legal certainty and not be open to multiple interpretations.

\section{References}

[1] Huesin Abdulsalam, "Dilema Hukuman Rehabilitasi Narkoba", (https://tirto.id Accessed June 20, 2019)

[2] Fitri Resnawardhani, "Kepastian Hukum dalam Pasal 112 dan Pasal 127 UndangUndang Nomor 35 Tahun 2009 Tentang Narkotika" Lentera Hukum, Volume 6 Issues 1, 2019, p. 119.

[3] Tri Agus Gunawan, "Analisis Yuridis Terhadap Ketentuan Pasal 112 Ayat (1) Undang-Undang Nomor 35 Tahun 2009 Tentang Narkotika Pada Pecandu dan Penyalahguna Narkotika, Tesis, Universitas Islam Indonesia, 2013, p.166

[4] Merevisi Undang-Undang Narkotika, (https://hukum.tempo.co, Accessed 20 September 2019). 